\title{
Do the Number of Cigarettes Smokes per Day Contribute to the Incident of Malignant Cancer?
}

\author{
Risky Kusuma Hartono ${ }^{1,2 *}$, Sabariah Abd Hamid ${ }^{2}$, Muhammad Hafizurrachman ${ }^{1}$
}

\begin{abstract}
Background: The incident of malignant cancer due to smoking habit becomes a public health problem especially in the developing countries. Active smokers neglect to stop smoking even though various studies proved that smoking increases the risk of cancer. While, previous studies have assessed the incident risk of cancer but have not performed the validity of the measurement. The aim of this study is to know the number of cigarettes that contribute to the incidence of malignant cancer. Methods: A study with retrospective cohort design has been conducted by using a set of public data of Indonesia Family Life Survey (IFLS) in 2007 and 2014. All active smokers ( $n=748)$ who were in good health condition in 2007, were traced in 2014 and then being diagnosed with cancer with considering age, gender, healthy eating habit, and regular physical activity. Data has been analysed by using logistic regression by performing Adjusted Risk Ratio (ARR) and the result of validity measurement. Results: The incident of malignant cancer in 2014 were skin, liver, stomach and oral cavity. Smoking 21-30 per day in 2007 were significantly increased risk of having malignant cancer in 2014 at ARR: 6.88; SE:6.13 with the accuracy were 93.8\%. The risk and accuracy were higher if smoke $>30$ cigarettes per day (ARR:7.523; SE:7.019; accuracy 95.5\%). This study also found that the risk of cancer was significantly increase with age (99\% CI; ARR: 1.065; SE: 0.026). Conclusions: Cigarette smoking behaviour increased the risk any types incident of cancer. Total number $>20$ cigarettes smoked per day contributes to the incidence of malignant cancer.
\end{abstract}

Keywords: Cigarettes- Malignant Cancer- Active Smokers- ARR- IFLS

Asian Pac J Cancer Prev, 20 (5), 1403-1408

\section{Introduction}

The incidences of cancer due to smoking behaviour become a public health problem and it is listed as the second leading cause of death globally (WHO, 2018). There are at least 17 types incident of cancer including larynx, lung, hypo pharynx, nasal cavities, bladder, oesophagus and liver due to cigarette smoking behaviour (Baade, 2015; Alexandrov, 2016). The dangerous chemicals in the cigarette smoked might change the DNA, triggering abnormalities cell, containing free radicals, carcinogenic and binding the blood fat are able to grow the cell of cancer (Gandini et al., 2008; Valavanidis et al., 2009; Moktar et al., 2011; Li et al., 2017). However, the manifestation of malignancy cancer needs a long period, which usually appear after 5-20 years (Hansen et al., 2013; Furrukh, 2013). It also depends on the increasing of age and human antibodies in preventing the unique proteins expressed on tumour cells (Young et al., 2009; Spits and Neefjes, 2016). Studies also have shown that antioxidants as a human antibody can be increased by regular physical activity, and consuming fruits and vegetables (Palafox Carlos et al., 2011; Liu, 2013).
According to the World Health Organization (WHO), $80 \%$ of the world's smokers live in low and middleincome countries and more than half of the world's smoking-addicted population resides in the Asia-Pacific region (WHO, 2015; Ho et al., 2018). In Indonesia, cancer due to smoke causes 74.440 people death with the dominant cases happens in man (95\%) (Riskesdas, 2013; Kristina et al., 2015; Tandilittin, 2016). The warning label is no longer acts as a motivation factor to quit smoking immediately due to lack of credibility and inevitability related to the fatalism of the diseases on the label (Mead et al., 2015). Smokers have a desire to stop smoking only after they have suffered with diseases due to smoking (Mannino, 2009). Although many studies have proven that smoking increases the risk of any types of cancer (Gandini et al., 2008; Young et al., 2009; Hansen et al., 2013; Alexandrov, 2016; Crane et al., 2016; Spits and Neefjes, 2016) and have shown the incident risk of cancer based on the number of cigarettes smoked per day but none of the studies have performed the validity of the measurement (Morris et al., 1997; Catsburg et al., 2015).

This study aims to determine the number of cigarettes that contributes to the incidence of malignant cancer by 
using Indonesia Family Life Survey (IFLS) 2007 and 2014 data. The result of this study can be used as the additional information by health personnel to give health education to the active smoker to stop smoking.

\section{Materials and Methods}

\section{Study design}

This study used a quantitative method by using retrospective cohort design. Fixed cohort was the type of this study with the beginning in 2007 and followed up in 2014.

\section{Data Source}

The data was taken from the longitudinal surveys of social, economic, health, and household in Indonesia called Indonesia Family Life Survey (IFLS). The IFLS is a repeated survey and the only one public survey for interviewing the same respondents in the different time that has been done for five times (in 1993, 1997, 2000, $2007,2014)$ to collect information about individual, household and community level data using multistage stratified sampling. The original sampling frame was based on households from 13 out of 27 Indonesian provinces which represented $83 \%$ of Indonesia's population (IFLS, 2014).

\section{Participant of Study}

The population in this study were all the same respondents that have been interviewed in IFLS 4 (2007) and IFLS 5 (2014) data and the sample is the same respondents who meet the inclusion criteria. The minimum five years duration from 2007 till 2014 has been used following a result of Framingham study, which stated that the manifestation of Non-Communicable Disease (NCD) including cancer required minimum of five years (Coleman et al., 2007). The inclusion criteria were all the active smokers at the minimum age of 15 years in 2007 and without any acute or chronic illness diagnosed by the medical doctors. The incidence of malignant cancer among active smokers were traced in 2014 based on IFLS 5 (2014) as a follow up data. Based on the inclusion criteria, 748 fixed respondents were successfully tracked in 2007 and 2014.

\section{Variables}

Dependent variable of this study was the incident of malignant cancer and independent variable was the number of cigarettes smokes per day that was divided into 1-10, 11-20, 21-30 and $>30$ based on the result of previous studies (Morris et al., 1997; Catsburg et al., 2015). Covariate of this study were age, level of education, Body Mass Index (BMI), routine physical activity and routine consuming fruits and vegetables were selected, based on the significant previous studies (Palafox Carlos et al., 2011; Liu, 2013; Vineis and Wild, 2014; Catsburg et al., 2015).

\section{Statistical analysis}

Multivariate analysis was done by using logistic regression which performing Adjusted Risk Ratio (ARR) and Standard Error (SE). This study performed validity analysis by cigarette smoked per day. Validity analysis was done by performing Area Under Curve (AUC) of Receiver Operating Characteristic (ROC), correctly classified, Hosmer Lemeshow test, sensitivity, specificity and accuracy.

\section{Results}

Majority of smokers in 2007 and 2014 were male (94\%) and last education level were in elementary school (39\%) (Table 1). The proportion of active smokers who physically active increased from $32 \%$ (2007) to $49 \%$ (2014). However, active smokers with overweight increased ( $19 \%$ to $27 \%$, respectively) and routine consuming fruits and vegetables decreased (52\% to $48 \%$, respectively). Respondents who smoked $>30$ cigarettes per day increased from 4\% (2007) to 7\% (2014).

Table 2 showed that the incidence of malignancy cancer in 2014 was $0.9 \%$. There were also active smokers who have been diagnosed with skin, liver, stomach and oral cavity cancer $(0.4 \%, 0.3 \%, 0.1 \%, 0.1 \%$, respectively) In 2014.

Between 2007 and 2014, the number of smokers who smoke $>30$ cigarettes per day have been increased among productive age (from $67.7 \%$ to $80.4 \%$ ) and residing in urban area (from $54.8 \%$ to $58.9 \%$ ) (Table 3). Although there were increasing in doing physical activity $(32 \%$ to $50 \%$ ), the routine consuming fruits and vegetables were decreasing from $58.1 \%$ (2007) to $46.4 \%$ (2014).

After being controled with covariate, smoking 21-30 cigarettes per day in 2007 were significantly having the risk of malignant cancer in 2014 at ARR: 6.88; SE:6.13. The risk and accuracy were higher if smoke $>30$ cigarettes per day (ARR:7.523; SE:7.019) (Table 4).

The accuracy between smoking 21-30,>30 cigarettes per day in 2007 and having malignant cancer were $93.8 \%$, $95.5 \%$, respectively (Table 5 ). It means that the precision measurement between smoking at least 21 cigarettes per day in 2007 and the positive risk of malignant cancer in 2014 were at least 94\%. Hosmer Lemeshow test also showed $1.00(p>0.05)$ which means that the analysis result can be accepted as a fit analysis model.

\section{Discussion}

Result of this study showed that smoking cigarettes per day at total number 21-30 $(\mathrm{ARR}=6.883)$ and $>30$ $(\mathrm{ARR}=7.523)$ increased the risk of having malignant cancer. Other studies also find the same result related to dose response between smoking behaviour. According to Catsburg et al., (2015) smoking 20-29 and 30-39 cigarette per day as a heavy smokers and increased risk of breast cancer at $(\mathrm{HR}=1.14$ and $\mathrm{HR}=1.10$, respectively) and result study of Morris et al., (1997) stated that smoking $>25$ cigarette per day increased risk 18 times to be diagnosed with lung cancer. Most recent epidemiological studies also find the consistency positive association between smoking and any types of cancer (Gandini et al., 2008; Young et al., 2009; Hansen et al., 2013; Alexandrov, 2016; Crane et al., 2016; Sohn and Jung, 2016; Spits and Neefjes, 2016). In 
DOI:10.31557/APJCP.2019.20.5.1403

Cigarettes Smokes per Day and Malignant Cancer

Table 1. The Dynamic Characteristics of the Active Smokers Respondents, 2007 and 2014

\begin{tabular}{|c|c|c|c|c|c|c|}
\hline \multirow[t]{2}{*}{ Variables } & \multicolumn{3}{|c|}{$2007(\mathrm{~N}=748)$} & \multicolumn{3}{|c|}{$2014(\mathrm{~N}=748)$} \\
\hline & Mean \pm SE & Min & Max & Mean \pm SE & Min & Max \\
\hline \multicolumn{7}{|l|}{ Socio Demographic and Economic Condition } \\
\hline Age & $39.89 \pm 14.79$ & 15 & 87 & $46.81 \pm 14.81$ & 21 & 94 \\
\hline Gender (Male) & $0.94 \pm 0.22$ & 0 & 1 & $0.95 \pm 0.22$ & 0 & 1 \\
\hline Marital status (Married) & $0.85 \pm 0.35$ & 0 & 1 & $0.92 \pm 0.26$ & 0 & 1 \\
\hline Widow & $0.02 \pm 0.01$ & 0 & 1 & $0.04 \pm 0.007$ & 0 & 1 \\
\hline Moslem religion & $0.89 \pm 0.31$ & 0 & 1 & $0.89 \pm 0.31$ & 0 & 1 \\
\hline \multicolumn{7}{|l|}{ Last education level } \\
\hline Elementary school & $0.39 \pm 0.04$ & 0 & 1 & $0.39 \pm .0 .04$ & 0 & 1 \\
\hline Junior high school & $0.17 \pm 0.03$ & 0 & 1 & $0.17 \pm 0.03$ & 0 & 1 \\
\hline Senior high school & $0.26 \pm 0.04$ & 0 & 1 & $0.26 \pm 0.04$ & 0 & 1 \\
\hline College & $0 \pm 0$ & 0 & 1 & $0 \pm 0$ & 0 & 1 \\
\hline Residing in urban area & $0.47 \pm 0.05$ & 0 & 1 & $0.55 \pm 0.49$ & 0 & 1 \\
\hline Having own house & $0.78 \pm 0.04$ & 0 & 1 & $0.78 \pm 0.41$ & 0 & 1 \\
\hline \multicolumn{7}{|l|}{ Health Measurement } \\
\hline BMI & $26.34 \pm 9.86$ & 9.7 & 27.1 & $22.65 \pm 4.06$ & 14.5 & 39.9 \\
\hline Underweight (18.5) & $0.17 \pm 0.03$ & 0 & 1 & $0.13 \pm 0.03$ & 0 & 1 \\
\hline Normal (18.5-24.9) & $0.64 \pm 0.04$ & 0 & 1 & $0.60 \pm 0.05$ & 0 & 1 \\
\hline Overweight $\geq 25$ & $0.19 \pm 0.03$ & 0 & 1 & $0.27 \pm 0.04$ & 0 & 1 \\
\hline Routine doing physical activity & $0.32 \pm 0.04$ & 0 & 1 & $0.49 \pm 0.05$ & 0 & 1 \\
\hline Routine consuming fruits and vegetables & $0.52 \pm 0.04$ & 0 & 1 & $0.48 \pm 0.05$ & 0 & 1 \\
\hline Smoking per day & $11.71 \pm 8.11$ & 1 & 60 & $13.36 \pm 9.26$ & 1 & 64 \\
\hline $1-10$ & $0.45 \pm 0.04$ & 0 & 1 & $0.39 \pm 0.04$ & 0 & 1 \\
\hline $11-20$ & $0.46 \pm 0.05$ & 0 & 1 & $0.47 \pm 0.05$ & 0 & 1 \\
\hline $21-30$ & $0.06 \pm 0.02$ & 0 & 1 & $0.07 \pm 0.02$ & 0 & 1 \\
\hline$>30$ & $0.04 \pm 0.01$ & 0 & 1 & $0.07 \pm 0.03$ & 0 & 1 \\
\hline
\end{tabular}

SE, Standard Error; BMI, Body Mass Index

contrary, cigarette smoking was significantly associated with a decreased risk of endometrial cancer only among postmenopausal women and this condition depends on their obesity status (Zhou et al., 2008; Polesel et al., 2009).

Types of malignant cancer based on the result of this study were skin, liver, stomach and oral cavity cancer. This result has a contradiction with several studies that stated most of the type of cancer due to smoking habit is lungs cancer (Morris et al., 1997; Furrukh, 2013; Crane et al., 2016; Spits and Neefjes, 2016). However, previous studies stated that there are at least 17 types incident of cancer due to cigarette smoking behaviour (Baade, 2015;
Alexandrov, 2016). It happens due to the accumulation of dangerous chemicals in cigarettes which are able to divide the DNA in cells into abnormalities in all part of bodies (Morris et al., 1997; Valavanidis et al., 2009; Moktar et al., 2011). Moreover, at least 60 chemicals in cigarette are carcinogens including arsenic as a major cause of skin and liver cancer and benzoapyrene as a major cause of lung cancer and oral cavity cancer (Valavanidis et al., 2009; Li et al., 2017). Praud et al., (2018) stated that the risk of gastric cancer depends on dose and duration of smoking, and the decrease in risk following stopping smoking.

The accuracy measurement between smoking 21-30

Table 2. The Incidence and Type of Malignancy Cancer, 2007 and 2014

\begin{tabular}{lcccccc}
\hline Variables & \multicolumn{2}{c}{$2007(\mathrm{~N}=748)$} & \multicolumn{3}{c}{$2014(\mathrm{~N}=748)$} \\
& Mean \pm SE & Min & Max & Mean \pm SE & Min & Max \\
\hline Incidence of malignancy cancer & $0 \pm 0$ & 0 & 1 & $0.009 \pm 0.00$ & 0 & 1 \\
Types of malignancy cancer & & & & & & \\
$\quad$ Skin & $0 \pm 0$ & 0 & 0 & $0.004 \pm 0.00$ & 0 & 1 \\
Liver & $0 \pm 0$ & 0 & 0 & $0.003 \pm 0.00$ & 0 & 1 \\
Stomach & $0 \pm 0$ & 0 & 0 & $0.001 \pm 0.00$ & 0 & 1 \\
Oral Cavity & $0 \pm 0$ & 0 & 0 & $0.001 \pm 0.00$ & 0 & 1 \\
\hline
\end{tabular}


Table 3. Characteristics of Respondents Based on Smoking per Day in 2007 and 2014

\begin{tabular}{|c|c|c|c|c|c|c|c|c|}
\hline \multirow[t]{3}{*}{ Factors/ Covariate } & \multicolumn{8}{|c|}{ Proportion Based on Smoking per Day (\%) } \\
\hline & \multicolumn{4}{|c|}{2007} & \multicolumn{4}{|c|}{2014} \\
\hline & $1-10$ & $10-20$ & $21-30$ & $>30$ & $1-10$ & $10-20$ & $21-30$ & $>30$ \\
\hline \multicolumn{9}{|l|}{ Socio Demographic and Economic Condition } \\
\hline \multicolumn{9}{|l|}{ Age } \\
\hline $15-25$ years old (young) & 16.67 & 14.33 & 9.3 & 16.13 & 3.05 & 3.43 & 0 & 7.14 \\
\hline 26-55 years old (productive age) & 61.9 & 73.68 & 76.74 & 67.74 & 68.81 & 71.71 & 72 & 80.36 \\
\hline 55-65 years old (retirement) & 9.82 & 7.31 & 6.98 & 12.9 & 11.19 & 11.43 & 20 & 10.71 \\
\hline$>65$ (Elderly) & 11.61 & 4.68 & 6.98 & 3.23 & 16.95 & 13.43 & 8 & 1.79 \\
\hline Gender (Male) & 98.48 & 98.25 & 97.67 & 96.77 & 90.51 & 97.43 & 96.00 & 98.21 \\
\hline Marital Status (Married) & 83.33 & 85.38 & 93.02 & 90.32 & 95.25 & 93.14 & 98.00 & 92.86 \\
\hline Moslem Religion & 91.96 & 87.13 & 86.05 & 87.1 & 91.86 & 88 & 82.00 & 87.5 \\
\hline \multicolumn{9}{|l|}{ Level of Education } \\
\hline Elementary school & 44.05 & 36.84 & 37.21 & 12.9 & 44.05 & 34.57 & 38 & 30.36 \\
\hline Junior high school & 16.07 & 19.3 & 11.63 & 9.68 & 14.24 & 20 & 16 & 11.6 \\
\hline Senior high school & 23.21 & 26.9 & 32.56 & 45.16 & 24.21 & 30 & 26 & 41.07 \\
\hline College & 0.00 & 0.00 & 0.00 & 0 & 0.00 & 0.00 & 0.00 & 0.00 \\
\hline Residing in urban area & 46.43 & 46.2 & 65.12 & 54.84 & 54.58 & 52.00 & 60.00 & 58.93 \\
\hline Having own house & 79.17 & 78.07 & 76.74 & 80.65 & 81.69 & 76.29 & 76.00 & 71.43 \\
\hline \multicolumn{9}{|l|}{ Health Measurement } \\
\hline \multicolumn{9}{|l|}{ BMI } \\
\hline Underweight $(<18.5)$ & 19.05 & 14.91 & 16.28 & 16.13 & 16.27 & 12.86 & 6 & 5.36 \\
\hline Normal (18.5-24.9) & 65.18 & 66.96 & 46.51 & 41.94 & 58.31 & 62.00 & 64 & 57.14 \\
\hline Overweight $(\geq 25)$ & 15.77 & 18.13 & 37.21 & 41.94 & 25.42 & 25.14 & 30 & 37.5 \\
\hline Routine doing physical activity & 31.55 & 31.87 & 44.19 & 32.26 & 44.75 & 52.57 & 56 & 50 \\
\hline Routine consuming fruits and vegetables & 54.46 & 49.71 & 53.49 & 58.06 & 44.81 & 48.86 & 42 & 46.43 \\
\hline
\end{tabular}

BMI, Body Mass Index

Table 4. Factors of Smoking Per Day in 2007 for Being Diagnosed with Cancer in 2014

\begin{tabular}{|c|c|c|c|c|}
\hline \multirow[t]{2}{*}{ Variables } & \multicolumn{4}{|c|}{ Proportion Based on Number of Smoking Per day in ARR (SE) } \\
\hline & $1-10$ & $10-20$ & $21-30$ & $>30$ \\
\hline Smoking per day & $1.20(0.222)$ & $1.466(0.399)$ & $6.883(6.133)^{* *}$ & $7.523(7.019)^{* *}$ \\
\hline Age & $1.064(0.025)^{* * *}$ & $1.063(0.025)^{* * *}$ & $1.065(0.026)^{* *}$ & $1.064(0.025)^{* * *}$ \\
\hline Elementary school & $0.142(1.191)$ & $0.134(1.017)$ & $0.152(0.205)$ & $0.132(0.178)$ \\
\hline Junior high school & $0.574(1.727)$ & $0.669(0.842)$ & $0.766(0.978)$ & $0.644(0.812)$ \\
\hline Senior high school & $1.008(0.965)$ & $1.504(1.448)$ & $1.516(1.475)$ & $0.982(0.961)$ \\
\hline Residing in urban & $1.802(1.647)$ & $1.724(1.541)$ & $1.589(1.455)$ & $1.526(1.403)$ \\
\hline Having own house & $0.682(0.604)$ & $0.608(0.547)$ & $0.604(0.541)$ & $0.628(0.571)$ \\
\hline Overweight $(\geq 25)$ & $0.338(0.372)$ & $0.399(0.436)$ & $0.329(0.365)$ & $0.364(0.401)$ \\
\hline Routine physical activity & $0.181(0.167)$ & $0.201(0.218)$ & $0.176(0.193)$ & $0.193(0.210)$ \\
\hline Routine consuming fruits and vegetables & $0.827(0.652)$ & $0.804(0.630)$ & $0.837(0.661)$ & $0.835(0.668)$ \\
\hline Constanta & $0.001(0.0002)^{* * *}$ & $0.001(0.00185)^{* * *}$ & $0.0005(0.0001)^{* * *}$ & $0.0007(0.001)^{* * *}$ \\
\hline \multicolumn{5}{|c|}{ ARR, Adjusted Risk Ratio; SE, Standard Error; ${ }^{* * *} \mathrm{p}<0.01,{ }^{* *} \mathrm{p}<0.05,{ }^{*} \mathrm{p}<0.1$} \\
\hline \multirow{3}{*}{ Validity } & \multirow{2}{*}{\multicolumn{4}{|c|}{ Proportion Based on Number of Smoking Per day }} \\
\hline & & & & \\
\hline & $1-10$ & $10-20$ & $21-30$ & $>30$ \\
\hline Pseudo R2 & 0.178 & 0.156 & 0.187 & 0.188 \\
\hline Hosmer Lemeshow test & 1 & 1 & 1 & 1 \\
\hline Correctly Classified & $99.53 \%$ & $99.53 \%$ & $99.53 \%$ & $99.53 \%$ \\
\hline AUC & 0.861 & 0.857 & 0.861 & 0.902 \\
\hline Sensitivity & 0.002 & 0.006 & 0.011 & 0.016 \\
\hline Specificity & 0.993 & 0.996 & 0.996 & 0.996 \\
\hline Accuracy & 0.589 & 0.549 & 0.938 & 0.955 \\
\hline
\end{tabular}


and $>30$ cigarettes per day and the risk of having cancer showed $93.8 \%$ and $95.5 \%$, respectively. This result improved the possibility of positive risk of the incident of malignant cancer through the validity analysis as reported by Hussain (2008) in which the validity analysis in logistic regression is important to evaluate and select the most influential risk factors. Although the manifestation of cancer needs a longer period (Hansen et al., 2013; Furrukh, 2013), this finding may increase awareness and motivation to stop smoking early among the smokers. Vineis and Wild, (2014) emphasized that $45 \%$ risk of cancer could be prevented if active smokers stopped smoking early. One of the significant ways to strengthen the motivation of active smokers to stop smoking early is by participating in smoking cessation counselling over the course of 5 days and 4 nights trough psychological and pharmacological therapy by health personnel in the primary health care (Yeom et al., 2018).

This study identified that active smokers mostly come from the respondents with elementary school level (Table 1), which supported with other studies that report men with low education have higher prevalence of heavy smoking in Croatia (Samardzic et al., 2009) and smokers with less education level were less likely to quit smoking successfully than those who have higher education (Piper et al., 2010). More years of education may enhance greater awareness on the harm of smoking which is why individuals with higher education levels avoid smoking (Samardzic et al., 2009). In contrary, according to Li and Powdthavee, (2015) people with high education level improves their diets and tendency to engage in more regular exercise, but not necessarily their tendency to avoid smoking. This result may suggest to the Ministry of Health in collaboration with the Ministry of Education in Indonesia to include the curriculum of smoking prevention in elementary school students.

This study showed that age was the only significant variable associated with the risk of cancer (Table 3). This finding is supported by another study that states the risk of cancer was significantly increased in those who quit smoking at 50 years of age (Ilic et al., 2013). Jung et al., (2016) also reports that the lung cancer rates for individuals 35 to 69 of age were approximately 2.6 times higher in smokers than in non-smokers among men and 2.0 times greater in smokers than in non-smokers among women. The positive association between age and the risk of cancer is due to reactive oxygen species mediated oxidative damage to lipids, proteins and DNA is heavily involved in the progress of aging and neurodegenerative diseases (Radak et al., 2011). Unfortunately, the young people have a perception that the risk of NCD including cancer is still lower than the adults aged middle-aged and older (Kaba and Khamisa, 2017). So that, only positive and productive aging with healthy lifestyle will become healthy aging and prevent from NCD including cancer (Patzelt et al., 2016).

This study has some limitation including the data, variables and years based on the observation on the data of IFLS 2007 and 2014. Further study by using primary data and more specific variables will help to increase quality result of the study. However, this study may support the evidence from public health aspect related to the incident of malignant cancer based on the number of cigarettes smoked per day.

In conclusion, this study concludes that the total number $>20$ cigarettes smoked per day contributes to the incidence of malignant cancer.

Primary health care should strengthen the prevention program through smoking cessation clinic and counselling camp to the active smokers in order to motivate the smokers to stop smoking early. Ministry of Health in collaboration with the Ministry of Education in Indonesia should include the curriculum of smoking prevention in elementary school students.

\section{Funding Statement}

The authors received no financial support for the study, authorship, and publication of this article.

\section{Conflicts of interest}

The authors declare that there is no conflict interest for this study.

\section{Acknowledgements}

The authors thank to Rand Corporation who provide data of IFLS 2007 and 2014. This study was not financed because the data was taken from Rand Corporation which can be accessed on http://www.rand.org/labor/FLS/IFLS/ download.html.

\section{References}

Alexandrov LB (2016). Mutational signatures associated with Tobacco smoking in human cancer. Science, 354, 618-22.

Baade PD (2015). Estimating the change in life expectancy after a diagnosis of cancer among the Australian population. BMJ Open, 5, 1-8.

Catsburg C, Miller AB, Rohan TE (2015). Active cigarette smoking and risk of breast cancer. Int J Cancer, 2209, 2204-9.

Coleman RL, Stevens RJ, Retnakaran R HR (2007). Framingham, SCORE, and DECODE risk equations do not provide reliable cardiovascular risk estimates in type 2 diabetes. Diabetes Care, 30, 1292-4.

Crane M, Scott N, O'Hara BJ, et al (2016). Knowledge of the signs, symptoms and risk factors of lung cancer in Australia: Mixed methods study. BMC Public Health, 16, 508.

Furrukh M (2013). Tobacco smoking and lung cancer: Perception-changing facts. Sultan Qaboos Univ Med J, 13, 345-58.

Gandini S, Botteri E, Iodice S, et al (2008). Tobacco smoking and cancer: A meta-analysis. Int J Cancer, 122, 155-64.

Hansen RD, Albieri V, Tjonneland A, et al (2013). Effects of smoking and antioxidant micronutrients on risk of colorectal cancer. Clin Gastroenterol Hepatol, 11, 406-15.

Ho LM, Schafferer C, Lee JM, et al (2018). Raising cigarette excise tax to reduce consumption in low-and Middle-Income Countries of The Asia-Pacific Region: a simulation of the Anticipated Health and Taxation Revenues Impacts. BMC Public Health, 18, 1187.

Hussain JN (2008). Sensitivity analysis to select the most influential risk factors in a logistic regression model. Int $J$ Qual Stat Reliabil, 2008, 1-10.

IFLS (2014). The Fifth Wave of the Indonesia Family Life 
Survey (IFLS5): Overview and Field Report. RAND Coorperation, Indonesia.

Ilic M, Vlajinac H, Marinkovic J (2013). Cigarette smoking and breast cancer: a case-control study in Serbia. Asian Pac J Cancer Prev, 14, 6643-7.

Jung KJ, Jeon C, Jee SH (2016). The effect of smoking on lung cancer: Ethnic differences and the smoking paradox. Epidemiol Health, 38, e2016060.

Kaba Z, Khamisa N (2017). Age-group differences in risk perceptions of non-communicable diseases among adults in Diepsloot Township, Johannesburg, South Africa: A cross-sectional study based on the health belief model. S Afr Med J, 107, 797-804.

Kristina SA, Kristina SA, Endarti D, et al (2015). Burden of cancers related to smoking among the Indonesian population: Premature mortality costs and years of potential life lost. Asian Pac J Cancer Prev, 16, 6903-8.

Li J, Powdthavee N (2015). Does more education lead to better health habits? Evidence from the school reforms in Australia. Soc Sci Med, 127, 83-91.

Li W, Hu J, Adebali O, et al (2017). Human genome wide repair map of DNA damage caused by the cigarette smoke carcinogen Benzoapyrene. Proc Natl Acad Sci U S A, 114, 6752-7.

Liu RH (2013). Health promoting components of fruits and vegetables in the diet. Adv Nutr, 4, 384-92.

Mannino DM (2009). Why won't our patients stop smoking? The power of Nicotine addiction. Diabetes Care, 32, 426-8.

Mead EL, Cohen JE, Kennedy CE, et al (2015). The role of theory driven graphic warning labels in motivation to quit: a Qualitative study on perceptions from low-income, urban smokers. BMC Public Health, 15, 1-11.

Moktar A, Singh R, Vadhanam MV, et al (2011). Cigarette smoke condensate induced oxidative DNA damage and its removal in human cervical cancer cells. Int J Oncol, 39, 941-7.

Morris JK, Watt HC, Wald NJ (1997). The dose-response relationship between cigarette consumption, biochemical markers and risk of lung cancer. Br J Cancer, 75, 1690-3.

Palafox Carlos H, Ayala-Zavala JF, Gonzalez Aguilar GA (2011). The role of dietary fiber in the bioaccessibility and bioavailability of fruit and vegetable antioxidants. $J$ Food Sci, 76, 6-15.

Patzelt C, Heim S, Deitermann B, et al (2016). Reaching the Elderly: Understanding of health and preventive experiences for a Tailored approach-results of a qualitative study. $B M C$ Geriatr, 16, 210.

Piper ME, Cook JW, Schlam TR, et al (2010). Gender, race, and education differences in abstinence rates among participants in two randomized smoking cessation trials. Nicotine Tob Res, 12, 647-57.

Polesel J, Serraino D, Zucchetto A, et al (2009). Cigarette smoking and endometrial cancer risk: The modifying effect of obesity. Eur J Cancer Prev, 18, 476-81.

Praud D, Rota M, Pelucchi C, et al (2018). Cigarette smoking and gastric cancer in the stomach cancer pooling (StoP) project. Eur J Cancer Prev, 27, 124-33.

Radak Z, Zhao Z, Goto S, Koltai E (2011). Age-associated neurodegeneration and oxidative damage to lipids, proteins and DNA. Mol Aspects Med, 32, 305-15.

Riskesdas (2013). Riset Kesehatan Dasar (Riskesdas). Jakarta:Kementerian Kesehatan Republik Indonesia.

Samardzic S, Pristas I, Vuletic Mavrinac G (2009). Characteristics of heavy smokers in croatia. Coll Antropol, 33, 61-6.

Sohn M, Jung M (2016). Effects of public and private health insurance on medical service utilization in the National Health Insurance System: National panel study in the Republic of Korea. BMC Health Serv Res, 16, 1-11.
Spits M, Neefjes J (2016). Immunoproteasomes and immunotherapy a smoking gun for lung cancer?. J Thorac Dis, 8, 558-63.

Tandilittin H (2016). What should the government do to stop epidemic of smoking among teenagers in Indonesia?. Asian Cult History, 8, 140-54.

Valavanidis A, Vlachogianni T, Fiotakis K (2009). Tobacco smoke: Involvement of reactive oxygen species and stable free radicals in mechanisms of oxidative damage, carcinogenesis and synergistic effects with other respirable particles. Int J Environ Res Public Health, 6, 445-62.

Vineis P, Wild CP (2014). The cancer wars 1 global cancer patterns: Causes and prevention. Lancet, 383, 549-57.

WHO (2018). Cancer. In: World Heal. Organ. https://www.who. int/cancer/en/. Accessed 18 Apr 2019.

WHO (2015). WHO global report on trends in prevalence of tobacco smoking 2015. World Health Organization, Geneva.

Yeom H, Lim H, Min J, et al (2018). Factors affecting smoking cessation success of heavy smokers registered in the intensive care smoking cessation camp. Osong Public Health Res Perspect, 9, 240-7.

Young E, Leatherdale S, Sloan M, et al (2009). Age of smoking initiation and risk of breast cancer in a sample of Ontario women. Tob Induc Dis, 5, 4.

Zhou B, Yang L, Sun Q, et al (2008). Cigarette smoking and the risk of endometrial cancer: a meta-analysis. $\mathrm{Am} \mathrm{J} \mathrm{Med,}$ 121, 501-8.

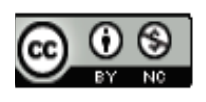

This work is licensed under a Creative Commons AttributionNon Commercial 4.0 International License. 